\title{
IS TAIWAN'S R\&D PRODUCTIVITY IN DECLINE? A MICROECONOMETRIC ANALYSIS
}

\author{
Chih-Hai Yang ${ }^{1}$, Chia-Hui Huang ${ }^{2}$ \\ ${ }^{1}$ Department of Economics, National Central University, \\ 300 Jhongda Road, Jhongli 320, Taiwan \\ ${ }^{2}$ Department of Economics, Aletheia University, 32 Zhenli St, Danshui Dist, \\ New Taipei City 51, Taiwan \\ E-mails: 1 chyang@mgt.ncu.edu.tw (corresponding author); \\ 2chhuang@mail.au.edu.tw
}

Received 29 January 2011; accepted 09 July 2012

\begin{abstract}
Innovation is widely recognized as the main stimulus of economic growth. Considering that Taiwan has devoted increasingly more efforts to R\&D since the late 1980s, a crucial question is posed: did the R\&D productivity of firms begin to decline in Taiwan during the post-Asian Financial Crisis period when Taiwan's economic growth began to decelerate? This study investigates changes in R\&D productivity for Taiwan's manufacturing firms from 1990 to 2003. By employing various approaches to obtain robust results, findings from firm-level microeconometric analysis suggests that overall R\&D productivity in Taiwan appears to have been ascendant, particularly during the post-crisis period. This result is also evidenced by segmenting the sample into industry groups, whereby electronics firms have a significantly high $R \& D$ productivity growth relative to firms outside the electronics industry. Therefore, the slowdown of Taiwan's economic growth in the past decade is attributed to other influences rather than a slowdown in R\&D productivity.
\end{abstract}

Keywords: R\&D, patent, productivity, innovation.

Reference to this paper should be made as follows: Yang, C.-H.; Huang, C.-H. 2013. Is Taiwan's R\&D productivity in decline? A microeconometric analysis, Journal of Business Economics and Management 14(1): 137-155.

JEL Classification: I24, O32, O33.

\section{Introduction}

Innovation, as supported in relevant empirical literature, is widely recognized as a major stimulus of economic growth ${ }^{1}$. To transform the labor-intensive industries of the Taiwanese manufacturing structure to those that are technological and knowledgeintensive, both public and private sectors have, since the mid-1980s, devoted gradually increasing efforts to innovative activity and have achieved outstanding performance

\footnotetext{
${ }^{1}$ See Acemoglu et al. (2006) for a comprehensive survey of the interaction among the degree of economic development, $\mathrm{R} \& \mathrm{D}$, and economic growth.
} 
in various measures of innovation ${ }^{2}$. However, although Taiwan's innovation performance is distinguished and well known worldwide, its miracle of high economic growth seemed to change dramatically after the 1997 Asian financial crisis. From 1986 to 1997, Taiwan experienced an average growth rate of $7.63 \%$, whereas the average growth rate declined to $4.25 \%$ from 1998 to $2008^{3}$.

If innovation served as the primary stimulus of Taiwan's economic growth in the 1990s, a question remains: has Taiwan's stagnant post-crisis performance arisen because of its innovative productivity being on the decline? R\&D-based endogenous growth theories, such as those proposed by Romer (1990), Grossman and Helpman (1991), and Aghion and Howitt (1992) emphasize the role played by innovation in promoting economic growth. However, semi-endogenous theory, developed by Jones (1995), Kortum (1997), and Segerstrom (1998), incorporates the law of diminishing marginal returns into the stock of knowledge in $R \& D$. In other words, R\&D productivity may be a decreasing trend and there is no longer a positive relationship between the levels of $R \& D$ and productivity growth ${ }^{4}$.

Sustainable growth depends partly on the ability of firms to develop new technologies. Based on the law of decreasing returns, if $R \& D$ productivity exhibits a decline, then one country alone cannot experience long-term economic growth, regardless of whether it continues to engage in R\&D activities. The decline in innovative capability had arguably been one of the primary causes of low economic growth in the United States during the 1970s (Griliches, Mairesse 1984), whereas R\&D productivity appeared to recover in the early 1980s (Lichtenberg, Siegel 1991). Using aggregate R\&D data for the United States during 1953-2000, Ha and Howitt (2007) found that growth in R\&D inputs had declined significantly since 1953, while TFP growth during the same period had not displayed any downward trend. This phenomenon of declining R\&D productivity also occurred in France during the late 1980s (Hall, Mairesse 1995) and in Spain during the 1990s (Beneito 2001). Moreover, Branstetter and Nakamura (2003) investigated changes in the output and productivity of R\&D in Japan and discovered a slowdown that had transpired in the growth of Japanese research productivity in the 1990s. Based on the experiences of advanced countries, a decline in R\&D productivity seems to be inevitable.

By contrast, Madsen (2007) examined the hypothesis of diminishing returns to R\&D and showed that the null hypothesis of constant returns to R\&D cannot be rejected for OECD countries. Using long historical data for the United Kingdom from 1620 to

\footnotetext{
2 Please see Trajtenberg (2001) for the international comparison of patents granted in the U.S.

${ }^{3}$ The Asian Financial Crisis indeed was an exogenous shock on macroeconomic performance, though some Asian countries recovered from the shock quickly. For example, South Korea was knocked seriously by the Asian Financial Crisis, resulting in its economy declining -6.9\% in 1998. However, its economy recovered quickly and reached an average growth rate of $6.08 \%$ over 1999-2004.

${ }^{4}$ The semi-endogenous models have been motivated by graphical evidence of a decline in R\&D productivity in the USA (Kortum 1993; Griliches 1994; Madsen 2008) and in the UK, Germany and France (Evenson 1993).
} 
2006, Madsen et al. (2010) suggested that innovative activity was an important force in shaping the Industrial Revolution and showed that the growth miracle in India over the past five decades has been driven by research intensity. Using data for the six Asian miracle economies from 1953 to 2006, Ang and Madsen (2011) evidenced that R\&D growth and R\&D intensity have influenced Asian growth ${ }^{5}$. These results cast doubt on the assumption of diminishing returns to knowledge, and the implications of R\&Dbased theories remain unclear, particularly for developing economies. Therefore, the main purpose of this study was to determine whether R\&D productivity declines in a newly industrialized economy (NIE), specifically, in Taiwan. This question is critically relevant for Taiwan's long-term economic growth. In addition, determining whether continually investing in R\&D activity is worthwhile can yield insightful implications regarding the R\&D strategies of firms.

The remainder of this paper is organized as follows. The next section reviews Taiwan's innovative activities from both historical and comparative perspectives. Section 3 presents the empirical framework, estimation techniques, and dataset. Section 4 reports and discusses the estimates of the time trend of the innovative productivity of firms in Taiwan during the 1990s and early 2000s. Additional investigations on R\&D productivity for both the electronics industry and other industries are described in Section 5. Concluding remarks and policy implications are summarized in the final section.

\section{Taiwan's innovative activity: a historical and comparative perspective}

In the 1980s, Taiwan turned its focus on the development of high-tech industries and experienced a high level of growth that was driven by exporting labor-intensive products for three decades. The establishment of the Hsinchu Science-based Industrial Park (HSIP) can be marked as the milestone of industrial revolution in Taiwan ${ }^{6}$. Accordingly, both public and private sectors devoted increasingly more efforts to innovative activity. To set the stage for analysis, it is worth reviewing some of the evidence of Taiwan's expanding technological capability since the late 1980s.

Table 1 displays Taiwan's innovative activity since the late 1980s. Columns (1) and (2) list the R\&D spending and ratios of R\&D expenditure to GNP, respectively. The amount of R\&D expenditure has increased nearly sixfold: from NT\$43.839 billion in 1988 to NT\$331,386 billion in 2007. This steadily increasing trend of R\&D expenditure reveals that Taiwan had devoted considerable effort to scientific and technological development, in accordance with the need for industrial upgrading and economic growth. Correspondingly, the ratio of R\&D expenditures to GNP increased from $1.21 \%$ in 1988 to $2.62 \%$ in 2007, which are similar ratios to those of Germany and the U.S.

\footnotetext{
${ }^{5}$ The six miracle economies include: China, India, Japan, Korea, Singapore and Taiwan.

${ }^{6}$ Enormous changes in Taiwan's industrial environment occurred from the 1980s and onward. Not far after, environmental protection, increasing land and labor costs, and a violent fluctuation in Taiwan's local currency all emerged as major issues. In order to upgrade its economy towards technologyintensive and capital-intensive industries, as inspired by the success of California's Silicon Valley, Taiwan's government helped to establish HSIP.
} 
Table 1. Taiwan's innovative activity, 1988-2007

\begin{tabular}{ccccc}
\hline & $\begin{array}{c}(1) \\
\text { R\&D }\end{array}$ & $\begin{array}{c}(2) \\
\text { R\&D/GNP } \\
(\text { million NT })\end{array}$ & $\begin{array}{c}(3) \\
\text { Domestic Patent } \\
\text { Granted }\end{array}$ & $\begin{array}{c}(4) \\
\text { Patent } \\
\text { Granted/R\&D }\end{array}$ \\
\hline 1988 & 43,839 & 1.21 & 17,151 & 0.391 \\
1989 & 54,789 & 1.36 & 17,917 & 0.327 \\
1990 & 71,548 & 1.62 & 19,964 & 0.279 \\
1991 & 81,765 & 1.66 & 22,940 & 0.280 \\
1992 & 94,828 & 1.74 & 26,118 & 0.275 \\
1993 & 103,617 & 1.74 & 28,246 & 0.273 \\
1994 & 114,682 & 1.78 & 29,307 & 0.256 \\
1995 & 125,031 & 1.79 & 28,900 & 0.231 \\
1996 & 137,955 & 1.83 & 31,185 & 0.226 \\
1997 & 156,321 & 1.91 & 33,657 & 0.215 \\
1998 & 176,455 & 1.96 & 34,243 & 0.194 \\
1999 & 190,520 & 2.03 & 32,643 & 0.171 \\
2000 & 197,631 & 2.06 & 36,369 & 0.184 \\
2001 & 204,974 & 2.17 & 40,210 & 0.196 \\
2002 & 224,428 & 2.31 & 35,926 & 0.160 \\
2003 & 242,942 & 2.32 & 39,663 & 0.165 \\
2004 & 263,271 & 2.38 & 37,911 & 0.144 \\
2005 & 280,980 & 2.45 & 42,324 & 0.151 \\
2006 & 307,037 & 2.58 & 33,773 & 0.110 \\
2007 & 331,386 & 2.62 & 34,068 & 0.103 \\
\hline
\end{tabular}

Source: Indicators of Science and Technology of Taiwan, various issues. The process of issuing patents changed in 2004.

Concerning innovative outputs, columns (3) and (4) show Taiwan's patents granted to residents and the patents granted per NT\$1 million of R\&D expenditure, respectively. The number of domestic patents that were granted increased from 17,151 in 1988 to 42,324 in 2005 and then declined slightly. Notably, the number of patent applications by domestic inventors seems to have grown much more slowly after reaching a peak in 2005. The patent-R\&D ratio reflects the effectiveness of using $R \& D$ expenditure to generate innovations successfully. Column (4) shows that the number of patents generated per NT $\$ 1$ million of R\&D seems to decline steadily. Does this indicate that the R\&D productivity of Taiwanese firms has also declined? The decline in patents generated per NT\$1 million R\&D is, of course, one of the potential causes, attributable perhaps to the average cost of $R \& D$ projects having increased over time and/or because the average patent quality has improved.

Considering Taiwan's innovative capability from a comparative perspective, we focus on U.S. patents. Because of the importance of the U.S. market, Taiwanese firms are quite aggressive in their efforts to patent in the United States. Moreover, U.S. patents are usually sought first and foremost, because the standards for patentability are more stringent and it is the largest export-targeted country. Figure 1 illustrates the number of 


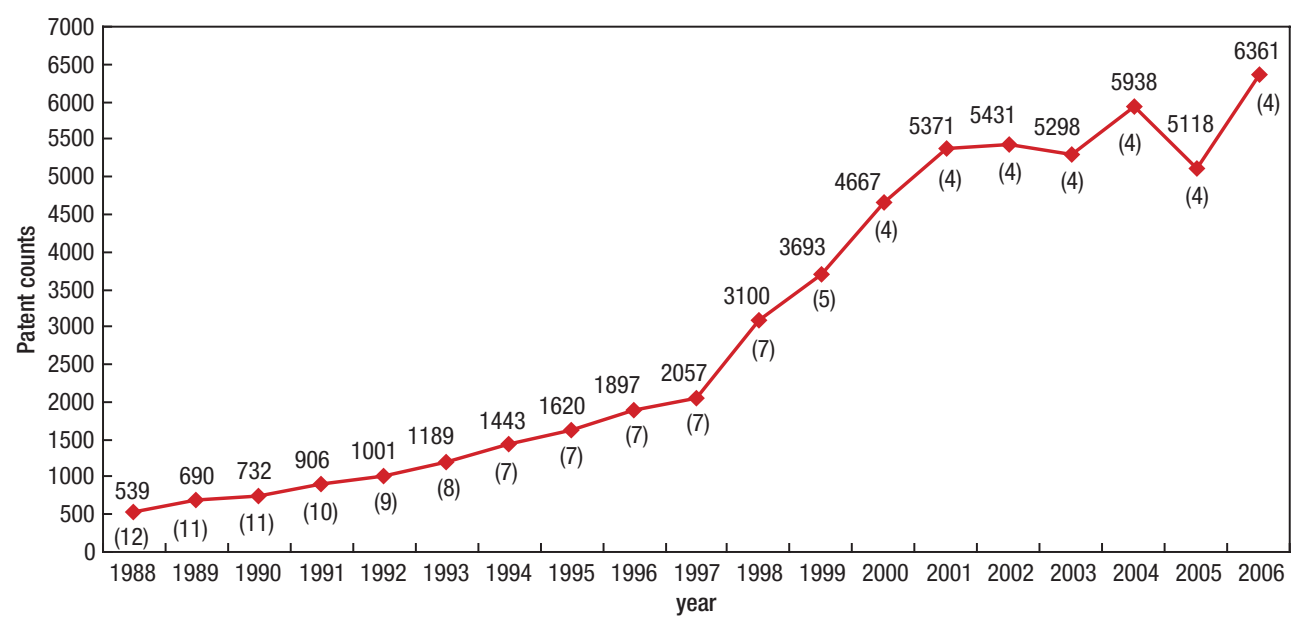

Fig. 1. Taiwan's patents approved in the U.S., 1988-2006

U.S. patents issued to Taiwanese inventors, as well as Taiwan's ranking among foreign inventors in the United States.

The number of Taiwanese patents granted in the United States has impressively grown by an average annual rate of $15.49 \%$, increasing from 539 in 1988 to 6361 in 2006; however, this growth seemed to decelerate after 2001. Figures in parentheses are the rankings of Taiwan-owned patents among foreign inventors in the United States. This information can be regarded as a measure of Taiwan's innovative capability relative to its international counterparts. A study of "influential patenting" by the technology consulting firm CHI, Inc. ranked Taiwan fourth worldwide in the quantity of its U.S. patents since 2000 . In the context of global firms competing under the same patent system with the same set of rules and examiners as in the United States, Taiwan appears to be closing the technological gap with its advanced counterparts ${ }^{7}$. Trajtenberg (2001) conducted an international comparison of U.S. patents and indicated that Taiwan ranks high in patents per capita, as compared to the G7 and other "Asian Tigers". Hence, R\&D and innovation have contributed significantly to productivity, particularly since 1990 (Chen, Yang 2006).

The conflicting data for economic growth and innovative activity prompts critical questions: is Taiwan's innovative capability on the decline? Furthermore, has the declining R\&D productivity, which has existed in developed countries during particular periods, occurred in Taiwan?

\footnotetext{
${ }^{7}$ Despite Taiwan receiving a large count of U.S. patents, its patents seem to have a low citation impact and a high self-citation. What the inside story is of this phenomenon is worth further investigating.
} 


\section{Empirical framework, estimation technique, and data}

To investigate whether Taiwan's innovative productivity has declined, we used data collected from R\&D inputs and outputs at the firm-level to estimate the knowledge production function used by Sakakibara and Branstetter (2001). For patents to be a measure of R\&D output, the knowledge production function for firm $i$ at time $t$ assumes the following form ${ }^{8}$ :

$$
P_{i t}=R_{i t}^{\beta} \Phi_{i t},
$$

$P_{i t}$ represents the flow of new-to-Taiwan technologies, (e.g., patent count). Term $R D$ is the key source of knowledge production, research and development expenditures,

where

$$
\Phi_{i t}=e^{\sum_{c} \gamma_{c} X_{i c t}} e^{\sum_{j} \theta_{j} D_{i j t} e^{\sum_{t} \delta_{t} T_{t}}} e^{u_{i t}} .
$$

The variable $\gamma$ s represents the difference in patenting caused by specific characteristics of firms, whereas $\theta$ s represents exogenous differences in technological opportunities among technological fields (industries) that are stable over time. Contingent on R\&D spending, as well as firm-specific and industry-specific characteristics, determining whether the overall effectiveness of the innovative activity of firms in Taiwan has been increasing, decreasing, or has remain unchanged over time is based on the pattern revealed by the estimates of $\delta$ s. If the time plots of $\delta$ s show a downward trend, then it implies a decline in R\&D productivity, common to all fields, over time.

Using the logs of both sides of Equation (2) yields the following log-linear equation:

$$
p_{i t}=\beta r_{i t}+\sum_{c} \gamma_{c} X_{i c t}+\sum_{j} \theta_{j} D_{i j t}+\sum_{t} \delta_{t} T_{t}+\varepsilon_{i t},
$$

where $r_{i t}$ is a firm's R\&D expenditure, $X$ is a vector of firm characteristics, $D$ is a vector of dummy variables for controlling differences in the propensity of patenting among industries, $T$ is a vector of year dummies, and $\varepsilon$ is an error term. To explore the time trend of the overall effectiveness of the R\&D productivity of firms, we replaced a series of year dummies with a series of interactive terms between R\&D and the year dummy. This allows the error term to contain a firm fixed effect that is time-invariant in the propensity of patenting among firms within industries. Because the firms in the sample did not change their primary industry affiliation over time, the industry effect is associated with the firm fixed effect. Referring to previous studies on the patent-R\&D nexus, the empirical model is specified as follows:

$$
\begin{aligned}
& P A T_{i t}=\beta_{0}+\beta_{1} \ln R D_{i t}+\beta_{2} S I Z E_{i t}+\beta_{3} \ln P C A P_{i t}+ \\
& \beta_{4} A D V R_{i t}+\beta_{5} \text { PROFIT }_{i t}+\gamma \ln R D_{i t} \times T+\varepsilon_{i t} .
\end{aligned}
$$

The dependent variable, PAT, is the number of successful patent applications of individual firms in year $t$. R\&D spending, in logarithm $(\ln R D)$, is the most crucial variable

\footnotetext{
${ }^{8}$ Though patent count is not a perfect measure of R\&D output, it constitutes a relevant measure of the technological effectiveness of R\&D activity (Griliches 1990).
} 
in the patent production function. Previous studies focusing on the R\&D-patent relationship have addressed the question of whether one the lag structure of R\&D expending can be identified, with most reaching the conclusion that the lag structure is poorly identified $^{9}$. Therefore, only a contemporaneous level of R\&D spending is included in the equation, following the specification of Hall and Ziedonis (2001).

The other variable considered is the size of the firm (SIZE), which is measured according to the logarithm of the number of employees. The Schumpeter hypothesis suggests that firms owning monopolistic power (usually large firms usually) tend to engage in innovation, and this hypothesis has been supported by many empirical studies ${ }^{10}$. Alternatively, Audretsch and Acs (1991) determined that small firms tend to outperform large firms in innovation in technologically intensive environments.

The term $\ln P C A P$ denotes a firm's capital intensity, measured as the logarithm of the ratio of physical capital to employees. Hall and Ziedonis (2001) argued that firms with large sunk costs respond strategically to institutional shifts by expanding their portfolios of patents with which to trade. $A D V R$ denotes a firm's advertisement intensity, measured as the ratio of advertising expenditure to sales. This variable is included to capture the toughness of competition within an industry and it is expected to influence the innovation behavior of firms positively. Moreover, the financing of innovation is widely discussed in relevant literature ${ }^{11}$. A firm's profitability (PROFIT) was included in this study to measure the availability of internal financial resources and it is expected to have a positive impact on the innovations of firms.

More importantly, a series of interaction terms between R\&D and annual time dummies for 1992-2003 is finally included in the empirical equation. The estimates of these interaction terms can be used to examine whether the overall effectiveness of firms' innovative activity has been increasing, decreasing, or has remain unchanged over time. The common shift in the time trend might be attributed to numerous other macro shocks, indicating that the change of patenting propensity for firms can be ascribed to many factors with no effect on the average. Therefore, the estimates of these interaction terms can be interpreted as the dynamics of firms' R\&D productivity.

Because the dependent variable, patent count, is a non-negative integer, a classical linear model is inadequate. For count data, the linear exponential family provides a favorable alternative. Therefore, we adopted the fixed effect negative binomial model developed by Hausman et al. (1984) to implement the empirical estimation.

The dataset used in this study contains 244 manufacturing firms listed on the Taiwan Stock Exchange (TSE) during 1990-2003, yielding an unbalanced panel of 3,136 ob-

\footnotetext{
${ }^{9}$ For example, one can review Hausman et al. (1984) and Cincera (1997). They find that the estimate of the sum of R\&D lag coefficients is roughly the same as the estimated coefficient of contemporaneous $R \& D$ when no lags are included.

${ }^{10}$ For example, please see Lerner (1995), and Hall and Ziedonis (2001).

${ }^{11}$ For the importance of financing on firms' R\&D, please see Hall (2002) for a comprehensive survey.
} 
servations. The data for patents granted to each firm were collected from the computer files of the Taiwan Intellectual Property Office. R\&D spending and other firm characteristics were obtained from the databank constructed by the Taiwan Economic Journal (TEJ) company ${ }^{12}$.

Is our dataset reasonably representative of Taiwanese industrial R\&D activity? As is well known, Taiwan's manufacturing sector is composed of an extremely high ratio, nearly 97\%, of small and medium-sized enterprises (SMEs), whereas R\&D spending and patenting have historically been highly concentrated in large industrial firms. Arising from the conditions for initial public offerings (IPO), most of the firms listed on the TSE belong to the classification of large enterprises. Moreover, the sample includes most of Taiwan's leading R\&D-performing firms, ensuring a thorough representation of the dataset. Table 2 summarizes the definition and basic statistics for each variable.

Table 2. Sample characteristics

\begin{tabular}{llc}
\hline \multicolumn{1}{c}{ Variable } & \multicolumn{1}{c}{ Definition } & Means (S.D) \\
\hline PAT & The number of successful patent applications & 5.444 \\
& & $(41.399)$ \\
RD & R\&D expenditure (NT\$ million) & 130.650 \\
SIZE & The number of employees & $(564.797)$ \\
& & 1141.742 \\
PCAP & Capital Intensity: the ratio of capital to employees & $(1687.012)$ \\
& (NT\$ million/person) & 4.273 \\
ADVR & Advertisement Intensity: the ratio of advertisement & $(6.461)$ \\
& expenditures to sales (\%) & 5.636 \\
PROFIT & Profitability: the firm's post-tax profitability (\%) & $(17.335)$ \\
& & 3.728 \\
\end{tabular}

Note: the means and standard deviations are calculated by pooling data for the 1991-2003 period.

Before implementing the empirical estimations, we first use the sample to observe the distribution of the total amount of $R \& D$ between electronics and non-electronics industries. Table 3 lists the amounts and percentages of R\&D expenditures for all manufacturing firms, as well as for electronics firms and non-electronics firms. As shown in Table 3, more than $70 \%$ of R\&D expenditure was contributed by electronics firms in the manufacturing sector during the sample period of 1990-2003. The electronics industry is the key industry in Taiwan's manufacturing sector regarding R\&D activities. Therefore, this study further separated the sample into two sub-groups: electronics

\footnotetext{
12 Taiwan Economic Journal is a commercial company that has a fine reputation on collecting and summarizing the information for companies listed on the Taiwan Stock Exchange. The TEJ data bank is reliable and widely adopted by most universities in Taiwan. This data bank contains comprehensive information for balance sheets, financial statements, annual reports, and so on.
} 
Table 3. The distribution of the total amount of R\&D, year by year

\begin{tabular}{cccccc}
\hline Year & $\begin{array}{c}\text { Manufacturing R\&D } \\
\text { (NT\$ million) }\end{array}$ & \multicolumn{2}{c}{$\begin{array}{c}\text { Electronics R\&D } \\
\text { (NT\$ million) }\end{array}$} & $\begin{array}{c}\text { Non-Electronics R\&D } \\
\text { (NT\$ million) }\end{array}$ \\
\hline 1990 & 7676 & 5681 & $(74.01)$ & 1995 & $(25.99)$ \\
1991 & 9957 & 7299 & $(73.31)$ & 2658 & $(26.69)$ \\
1992 & 10493 & 8833 & $(84.18)$ & 1660 & $(15.82)$ \\
1993 & 14434 & 11339 & $(78.56)$ & 3095 & $(21.44)$ \\
1994 & 18543 & 14699 & $(79.27)$ & 3844 & $(20.73)$ \\
1995 & 23812 & 19632 & $(82.45)$ & 4180 & $(17.55)$ \\
1996 & 27322 & 23082 & $(84.48)$ & 4240 & $(15.52)$ \\
1997 & 34555 & 29496 & $(85.36)$ & 5059 & $(14.64)$ \\
1998 & 33297 & 28416 & $(85.34)$ & 4881 & $(14.66)$ \\
1999 & 37409 & 32324 & $(86.41)$ & 5085 & $(13.59)$ \\
2000 & 52070 & 46981 & $(90.23)$ & 5089 & $(9.77)$ \\
2001 & 63323 & 58080 & $(91.72)$ & 5243 & $(8.28)$ \\
2002 & 65399 & 59771 & $(91.39)$ & 5628 & $(8.61)$ \\
2003 & 65980 & 60121 & $(91.12)$ & 5859 & $(8.88)$ \\
\hline
\end{tabular}

Note: the figures in parentheses are R\&D percentage.

firms and other manufacturing firms, to depict the dynamics of R\&D productivity for each group ${ }^{13}$.

\section{Empirical results}

Table 4 lists a series of estimates for the fixed effect negative binomial model using maximum likelihood methods. Column (1) includes only R\&D as the explanatory variable and it serves as the baseline model. Column (1) shows that the estimated patentR\&D elasticity is 0.119 , which is lower than estimates for the United States and OECD countries; for example, 0.90-0.98 for the U.S. manufacturing firms (Hall, Ziedonis 2001) and 0.90 for German firms (Licht, Zoz 1998). When other firm-specific characteristics are added into the model, as the estimates in column (2) show, the model's explanatory power improves with a substantial increase in the likelihood value. The coefficient for R\&D is significantly positive at a conventionally statistical level, whereas the magnitude of the elasticity decreases from 0.119 to 0.071 , which may arise from the importance of other determinants in influencing the patenting of firms.

\footnotetext{
${ }^{13}$ Following the definition of OECD, this study uses the mean of industrial R\&D intensity to classify industries into 'high-technology' or 'knowledge intensive' industries. According to the definition, electronic firms or pharmaceuticals firms are classified as knowledge intensive firms. However, Taiwanese pharmaceutical firms normally produce generic drugs rather than patent drugs. Therefore, we only treat electronics industry as knowledge intensive industry and compare electronics industry with other manufacturing industries.
} 
Table 4. Taiwan's R\&D productivity (FE negative binomial regression) 1991-2003

\begin{tabular}{|c|c|c|c|c|}
\hline Variable & (1) & (2) & (3) & (4) \\
\hline \multirow[t]{2}{*}{$\ln R D$} & $0.119 * * *$ & $0.071 * * *$ & 0.027 & 0.011 \\
\hline & $(0.016)$ & $(0.017)$ & $(0.018)$ & $(0.021)$ \\
\hline \multirow[t]{2}{*}{$\operatorname{lnSIZE}$} & & $0.162 * * *$ & & $0.134 * * *$ \\
\hline & & $(0.051)$ & & $(0.048)$ \\
\hline \multirow[t]{2}{*}{ lnPCAP } & & $0.277 * * *$ & & 0.027 \\
\hline & & $(0.044)$ & & $(0.050)$ \\
\hline \multirow[t]{2}{*}{ ADVR } & & $0.006 * * *$ & & $0.006 * * *$ \\
\hline & & $(0.001)$ & & $(0.001)$ \\
\hline \multirow[t]{2}{*}{ Profit } & & $0.003 * *$ & & $0.003 * *$ \\
\hline & & $(0.001)$ & & $(0.002)$ \\
\hline \multirow[t]{2}{*}{$92 * \ln R D$} & & & 0.022 & 0.015 \\
\hline & & & $(0.014)$ & $(0.016)$ \\
\hline \multirow[t]{2}{*}{$93 * \ln R D$} & & & 0.012 & 0.003 \\
\hline & & & $(0.014)$ & $(0.016)$ \\
\hline \multirow[t]{2}{*}{$94 * \ln R D$} & & & $0.025^{*}$ & 0.016 \\
\hline & & & $(0.013)$ & $(0.015)$ \\
\hline \multirow[t]{2}{*}{$95 * \ln R D$} & & & 0.019 & 0.009 \\
\hline & & & $(0.013)$ & $(0.016)$ \\
\hline \multirow[t]{2}{*}{$96 * \ln R D$} & & & $0.057 * * *$ & $0.044 * * *$ \\
\hline & & & $(0.012)$ & $(0.015)$ \\
\hline \multirow[t]{2}{*}{$97 * \ln R D$} & & & $0.047 * * *$ & $0.033 * *$ \\
\hline & & & $(0.013)$ & $(0.015)$ \\
\hline \multirow[t]{2}{*}{$98 * \ln R D$} & & & $0.062 * * *$ & $0.048 * * *$ \\
\hline & & & $(0.013)$ & $(0.016)$ \\
\hline \multirow[t]{2}{*}{$99 * \ln R D$} & & & $0.058 * * *$ & $0.046 * * *$ \\
\hline & & & $(0.013)$ & $(0.016)$ \\
\hline \multirow[t]{2}{*}{$00 * \ln R D$} & & & $0.068 * * *$ & $0.052 * * *$ \\
\hline & & & $(0.012)$ & $(0.016)$ \\
\hline \multirow[t]{2}{*}{$01 * \ln R D$} & & & $0.136 * * *$ & $0.125 * * *$ \\
\hline & & & $(0.011)$ & $(0.014)$ \\
\hline \multirow[t]{2}{*}{$02 * \ln R D$} & & & $0.131 * * *$ & $0.122 * * *$ \\
\hline & & & $(0.011)$ & $(0.015)$ \\
\hline \multirow[t]{2}{*}{$03 * \ln R D$} & & & $(0.153)^{* * *}$ & $0.146^{* * *}$ \\
\hline & & & $(0.011)$ & $(0.014)$ \\
\hline Log-likelihood & -3284.798 & -3041.298 & -3098.004 & -2890.203 \\
\hline Number of Obs. & 3,136 & 3,136 & 3,136 & 3,136 \\
\hline
\end{tabular}

Notes: The numbers in parentheses are standard errors. ***, **, and * represent the $1 \%, 5 \%$, and $10 \%$ significant levels, respectively. 
The estimated coefficient of SIZE is significantly positive at the $1 \%$ statistical level, supporting Schumpeter's hypothesis that large firms have the wherewithal to exploit innovations. The coefficient of capital intensity is positive and statistically significant at the $1 \%$ level. As expected, advertisement intensity exhibits a positive impact on the patenting of firms, implying that the toughness of competition within an industry can stimulate more innovation. The coefficient for a firm's profitability is significantly positive, indicating that the availability of internal financial resources is essential for their innovative activities.

Columns (3) and (4) are estimates obtained by including a series of interaction terms between R\&D and the year dummy. Controlling for R\&D expenditure and other firmspecific determinants, the coefficients of interaction terms are used to denote changes in the level of R\&D output that are common to all firms. In other words, controlling for R\&D expenditure and other firm-specific determinants indicates how innovative output is changing, on average, after controlling for inputs and other influences. Figure 2 shows the estimates for these interaction terms between R\&D and the year dummies listed in columns (3) and (4).

The two sets of plots for the coefficients on interaction terms appear as distinct patterns, suggesting that firms' R\&D productivity fluctuated and increased slightly before 1995, though it increased sharply in 1996 and exhibited a plateau during the mid-to-late 1990s. Why did the patenting productivity of Taiwanese firms surge forward in 1996? Before the early-1990s, the concept of the importance of intellectual property rights (IPRs) was weak for Taiwanese firms and their patenting behaviors were based on defensive reasons, such as avoiding IPR litigation and requests for royalty-bearing licenses from large international enterprises. As Taiwan's technological capability has gradually ascended, the innovation behaviors of Taiwanese firms have become more aggressive, with an aim at expanding international markets and defending against patent infringements. Taiwan's 1994 patent reform might also be an alternative cause that stimulated additional innovative outputs (Yang 2008).

The main concern of this study is whether Taiwan's declining economic growth that has continued since the late 1990 s can be plausibly attributed to the decline of firms'

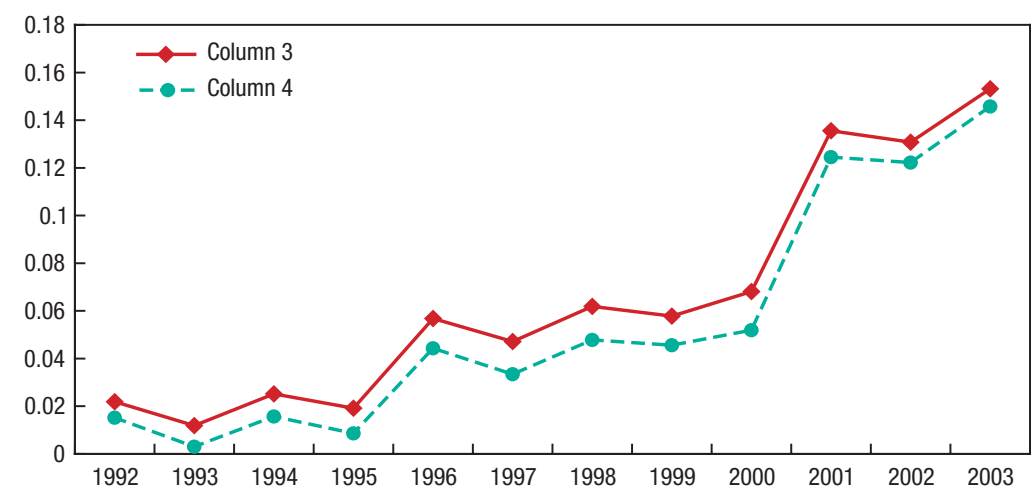

Fig. 2. Trend of firms' R\&D productivity in Taiwan, 1991-2003 
R\&D productivity. Surprisingly, after the Asian financial crisis, R\&D productivity demonstrated an accelerated increase that achieved an average growth rate of $22.70 \%$ annually during 1998-2003. Considering that there was no substantial change on the patent issue rate for domestic innovators from the early 1990 s to the early $2000 \mathrm{~s}^{14}$, the results above suggest that Taiwan's innovative productivity is increasing rather than declining. Thus, the poor performance of Taiwan's economic growth in recent years cannot be attributed to the decline in R\&D productivity. Alternatively, the level of performance might be caused by the large amounts of outward foreign direct investments that have replaced domestic investments, international economic shocks, and Taiwan's ruling political party turnover in 2000 .

Because Taiwan's manufacturing structure has become composed mainly of knowledgeintensive industries (e.g., information and community technology industries) since the early 1990s, examining the potential differences in the dynamics of R\&D productivity among industries is necessary. Does the continuing rise in $R \& D$ productivity since the mid-1990s occur in all firms or only in high-tech firms? This study further classified firms into electronics firms and other manufacturing firms and then implemented similar econometric techniques used in obtaining column 4 of Table 4 , to obtain the interaction terms between R\&D and the year dummy for electronics firms and other firms, respectively.

Figure 3 depicts the dynamics of R\&D productivity for both electronics firms and other manufacturing firms. The time trend of $R \& D$ productivity for electronics firms is quite similar to that of all firms (Figure 2), in that R\&D productivity grew sharply in 1996 and continued to grow slightly throughout the late-1990s. Specifically, R\&D productivity had been highly enhanced among electronics firms since the early 2000s. Compared to all firms, the performance in R\&D productivity for electronics firms is impressive, implying that the electronics industry has been the major driving force of growth through the 1990s and onward. By contrast, there is a slight but not insignificant decline in R\&D productivity for manufacturing firms outside the electronics industry before 2000. That is, con-

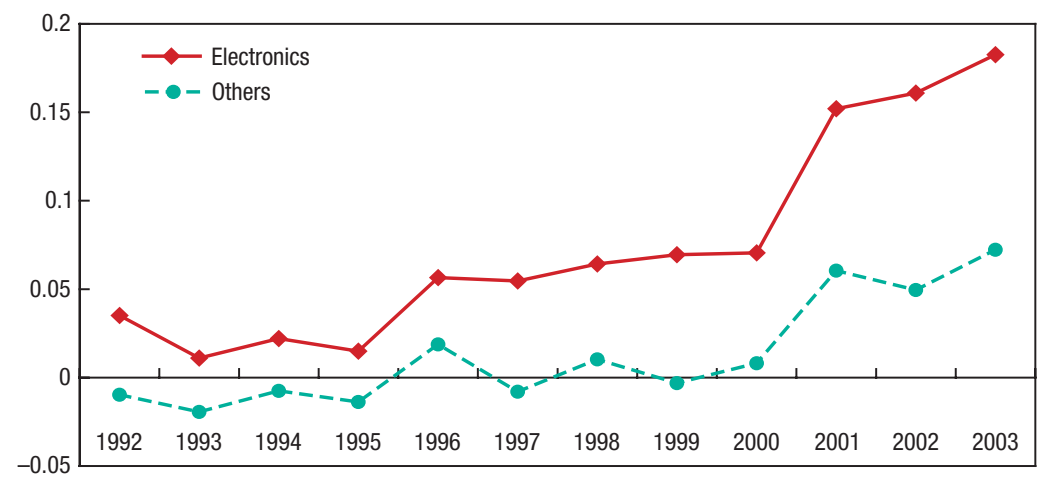

Fig. 3. Dynamics of R\&D productivity: electronics vs other manufacturing firms

\footnotetext{
${ }^{14}$ The average patent granted rate was 0.57 over the $1990-2003$ period. For the average patent granted rate over individual years, please refer to http://www.tipo.gov.tw
} 
trolling for innovative inputs and firm characteristics, non-high-tech firms experienced a constant R\&D productivity during the 1990s, on average. However, it is encouraging to see an increase in R\&D productivity for non-high-tech firms since the early 2000 s.

As shown in Figures 2 and 3, the R\&D productivity of both electronics firms and other manufacturing firms has increased substantially since the early 2000s, outperforming that in the 1990s. Therefore, microeconometric analysis does not support the suspicion that Taiwan's R\&D productivity has declined. Moreover, evidence from aggregate patents and R\&D statistics, as shown in Table 1 and Figure 2, also suggests that there is no slowdown in Taiwan's innovations over the 1990s and early 2000s. Therefore, the decline in economic growth must be caused by other influences rather than a slowdown in $R \& D$ productivity.

\section{An alternative investigation}

One may argue that firms undertaking R\&D to develop new products or processes, thereby aiming to increase profits, are mainly brought on by sales rather than patenting. Patents can serve as an effective output indicator of innovation, though it is widely recognized that many firms keep their innovations secret rather than apply for patenting (Cohen et al. 2000). Therefore, this study adopted an alternative approach to assess the R\&D productivity of firms by estimating the output elasticity of R\&D.

To measure the contribution of R\&D spending to output, the empirical specification follows the standard approach in analyzing the contribution of R\&D to productivity that has been widely adopted in previous studies (e.g., Griliches, Mairesse 1984; Hall, Mairesse 1995). A firm's production function can be approximated by using an augmented Cobb-Douglas function as follows:

$$
Y_{i t}=e^{\lambda t} C_{i t}^{\alpha} L_{i t}^{\beta} M_{i t}^{\gamma} R D_{i t}^{\varphi} e^{\varepsilon_{i t}},
$$

where $Y$ is the output that is measured by using a firm's sale, $C$ is the capital that is measured according to the value of fixed capital, $L$ is the labor input (number of employees), and $M$ is the intermediate inputs measured according to the sum of immediate materials (i.e., energy and power expenditures). Finally, $R D$ represents a firm's R\&D spending. The subscripts $i$ and $t$ refer to firm $i$ and year $t$, respectively, whereas $\lambda$ is the rate of disembodied exogenous technical change. To implement the estimation of the Cobb-Douglas function, we adopted logarithms and obtained the linear regression equation shown below:

$$
\ln Y_{i t}=\lambda_{t}+\alpha \ln C_{i t}+\beta \ln L_{i t}+\gamma \ln M_{i t}+\phi \ln R D_{i t}+\varepsilon_{i t},
$$

where $\varepsilon$ is a multiplicative disturbance, and $\alpha, \beta, \gamma$, and especially $\phi_{1}$ are the parameters of interest.

On exploring the time trend of the overall effectiveness of the R\&D productivity of firms, two strategies were employed in this study. First, this research estimated Equation (6) systematically by year to obtain the elasticity of R\&D productivity $(\phi)$ for various years and then plotted their time trend. Second, we adopted a coefficient-equality test 
to examine the possible difference in $R \& D$ productivity over particular years. That is, a series of interaction terms between R\&D expenditure and the year dummy are included in Equation (6) to demonstrate the dynamics of productivity. For the purpose of simplification, a regression model is specified as ${ }^{15}$ :

$$
\begin{aligned}
\ln Y_{i t}= & \lambda_{t}+\alpha \ln C_{i t}+\beta \ln L_{i t}+\gamma \ln M_{i t}+\phi \ln R D_{i t}+ \\
& \xi_{t} \ln R D_{i t} \times \text { Year Dummy }+\varepsilon_{i t} .
\end{aligned}
$$

Table 5 summarizes the estimates for R\&D productivity systematically by year, based on Equation (6). Column 4 of Table 5 shows that most coefficients for the R\&D variable

\begin{tabular}{|c|c|c|c|c|c|}
\hline $\begin{array}{c}\text { Variable } \\
\text { Year }\end{array}$ & $\ln C$ & $\ln L$ & $\ln M$ & $\ln R D$ & $\mathrm{R}^{2}$ \\
\hline 1990 & $\begin{array}{c}0.138 * * * \\
(0.034)\end{array}$ & $\begin{array}{c}0.293 * * * \\
(0.047)\end{array}$ & $\begin{array}{c}0.521 * * * \\
(0.051)\end{array}$ & $\begin{array}{c}0.008 \\
(0.005)\end{array}$ & 0.883 \\
\hline 1991 & $\begin{array}{c}0.198 * * * \\
(0.043)\end{array}$ & $\begin{array}{c}0.255^{* * * *} \\
(0.034)\end{array}$ & $\begin{array}{c}0.472 * * * \\
(0.053)\end{array}$ & $\begin{array}{c}0.012 * * \\
(0.005)\end{array}$ & 0.886 \\
\hline 1992 & $\begin{array}{c}0.150 * * * \\
(0.060)\end{array}$ & $\begin{array}{c}0.304 * * * \\
(0.047)\end{array}$ & $\begin{array}{c}0.450 * * * \\
(0.056)\end{array}$ & $\begin{array}{c}0.007 \\
(0.007)\end{array}$ & 0.844 \\
\hline 1993 & $\begin{array}{c}0.194 * * * \\
(0.044)\end{array}$ & $\begin{array}{c}0.278 * * * \\
(0.039)\end{array}$ & $\begin{array}{c}0.456 * * * \\
(0.050)\end{array}$ & $\begin{array}{l}0.010^{*} \\
(0.006)\end{array}$ & 0.863 \\
\hline 1994 & $\begin{array}{c}0.200 * * * \\
(0.045)\end{array}$ & $\begin{array}{c}0.312 * * * \\
(0.053)\end{array}$ & $\begin{array}{c}0.355^{* * *} * \\
(0.093)\end{array}$ & $\begin{array}{c}0.013 * * \\
(0.006)\end{array}$ & 0.789 \\
\hline 1995 & $\begin{array}{c}0.199 * * * \\
(0.049)\end{array}$ & $\begin{array}{c}0.314 * * * \\
(0.046)\end{array}$ & $\begin{array}{c}0.434 * * * \\
(0.050)\end{array}$ & $\begin{array}{l}0.013 * \\
(0.007)\end{array}$ & 0.834 \\
\hline 1996 & $\begin{array}{c}0.155^{* *} \\
(0.068)\end{array}$ & $\begin{array}{c}0.364 * * * \\
(0.055)\end{array}$ & $\begin{array}{c}0.439 * * * \\
(0.062)\end{array}$ & $\begin{array}{c}0.012 * * \\
(0.00)\end{array}$ & 0.840 \\
\hline 1997 & $\begin{array}{c}0.137 * * \\
(0.061)\end{array}$ & $\begin{array}{c}0.388 * * * \\
(0.051)\end{array}$ & $\begin{array}{c}0.366 * * * \\
(0.062)\end{array}$ & $\begin{array}{l}0.012 * \\
(0.006)\end{array}$ & 0.797 \\
\hline 1998 & $\begin{array}{c}0.187 * * * \\
(0.065)\end{array}$ & $\begin{array}{c}0.590 * * * \\
(0.156)\end{array}$ & $\begin{array}{c}0.076 \\
(0.154)\end{array}$ & $\begin{array}{c}0.016 \\
(0.011)\end{array}$ & 0.651 \\
\hline 1999 & $\begin{array}{c}0.231 * * * \\
(0.072)\end{array}$ & $\begin{array}{c}0.523 * * * \\
(0.149)\end{array}$ & $\begin{array}{c}.0880 \\
(0.154)\end{array}$ & $\begin{array}{c}0.030 * * * \\
(0.011)\end{array}$ & 0.657 \\
\hline 2000 & $\begin{array}{c}0.199 * * * \\
(0.074)\end{array}$ & $\begin{array}{c}0.539 * * * \\
(0.148)\end{array}$ & $\begin{array}{c}0.084 \\
(0.143)\end{array}$ & $\begin{array}{c}0.029 * * \\
(0.014)\end{array}$ & 0.637 \\
\hline 2001 & $\begin{array}{c}0.180 * * * \\
(0.058)\end{array}$ & $\begin{array}{c}0.599 * * * \\
(0.135)\end{array}$ & $\begin{array}{c}0.069 \\
(0.095)\end{array}$ & $\begin{array}{l}0.027 * \\
(0.014)\end{array}$ & 0.665 \\
\hline 2002 & $\begin{array}{c}0.180 * * \\
(0.079)\end{array}$ & $\begin{array}{c}0.630 * * * \\
(0.127)\end{array}$ & $\begin{array}{c}0.057 \\
(0.058)\end{array}$ & $\begin{array}{l}0.030^{*} \\
(0.016)\end{array}$ & 0.660 \\
\hline 2003 & $\begin{array}{c}0.233 * * * \\
(0.086)\end{array}$ & $\begin{array}{c}0.625 * * * \\
(0.100)\end{array}$ & $\begin{array}{c}0.031 \\
(0.049)\end{array}$ & $\begin{array}{c}0.032 * * \\
(0.014)\end{array}$ & 0.648 \\
\hline
\end{tabular}

Table 5. Taiwan's R\&D productivity, year by year

Notes: The numbers in parentheses are heteroscedastic-consistent standard errors. ***, **, and * represent the $1 \%, 5 \%$, and $10 \%$ significant levels, respectively.

${ }^{15}$ We employ the fixed effect panel data model to estimate equations (6) and (7). 
are significantly positive, implying that firms devoting more R\&D efforts demonstrated higher performance in productivity. More importantly, the magnitude of R\&D elasticity seems to have increased gradually over time and remained at approximately 0.01 through the early 1990s and increased to 0.016 through the late 1990s. In 1999, R\&D productivity increased sharply to 0.030 and has continued to grow thus far.

Figure 4 depicts the time trend of R\&D elasticity during 1991-2003, showing an obviously similar trend to that in Figure 3. Overall R\&D productivity exhibits an ascending trend, which can be roughly separated into three stages: R\&D productivity stagnated before 1994, increased slightly from the mid-1990s to the late-1990s, and then reached a plateau in 2000 and grew little thereafter. One point worth emphasizing is that Taiwan's R\&D productivity is ascending rather than descending. Therefore, we cannot argue that the poor post-financial crisis performance on economic growth in Taiwan is caused by a decline in $R \& D$ productivity.

The dynamics of R\&D productivity obtained by estimating Equation (7), using the fixed effect of the panel data model, are displayed in Figure 5.

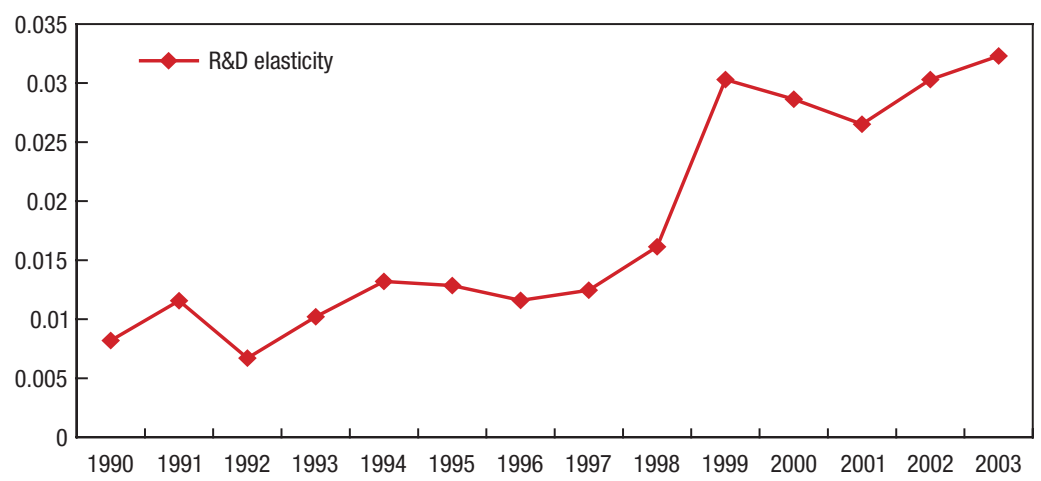

Fig. 4. Trend in elasticity of R\&D productivity

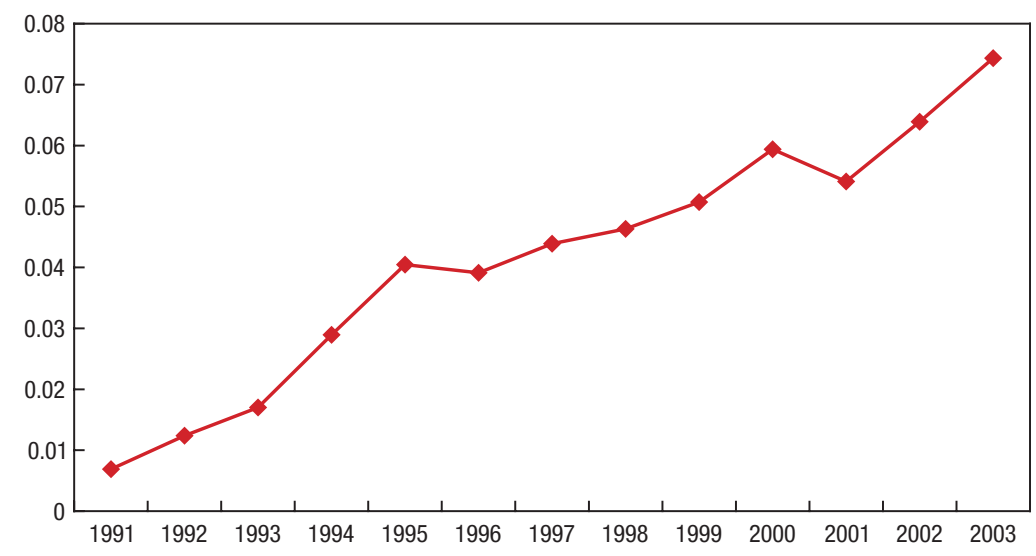

Fig. 5. The year differences on R\&D elasticity 
Figure 5 reveals a clearer picture of R\&D productivity increasing more stably during the study period, suggesting that Taiwan's R\&D productivity continues to rise. Splitting the sample into electronics and non-electronics firms and implementing the estimation technique used to obtain the findings shown in Figure 5, we plotted the dynamics of R\&D productivity for both electronics firms and other manufacturing firms in Figure 6.

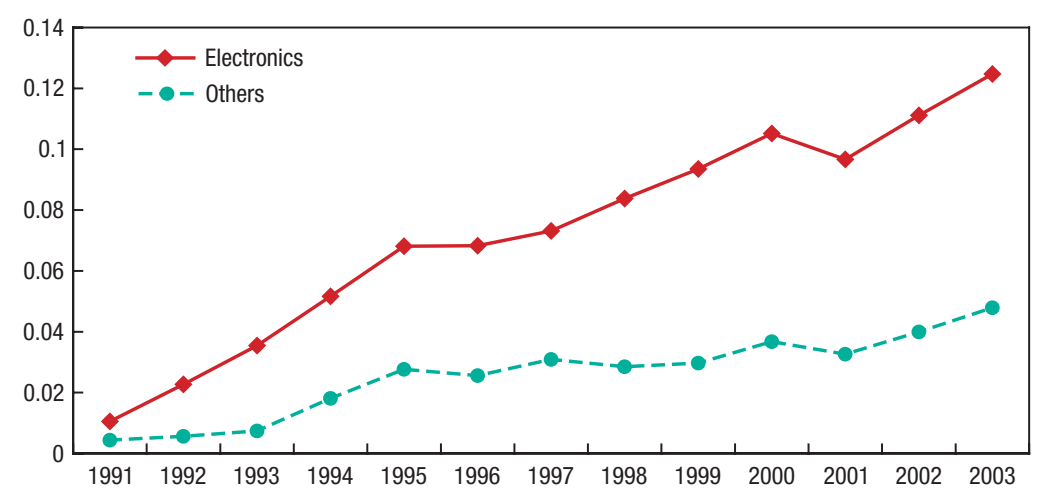

Fig. 6. Year differences in $R \& D$ elasticity: electronics vs other manufacturing firms

The picture depicts a clear trend that both electronics firms and other manufacturing firms experienced a similar and increasing trend in R\&D productivity, though there is a significant difference in R\&D productivity between electronics firms and other manufacturing firms. The increase in R\&D productivity for electronics firms is striking, whereas the performance of non-electronics firms is much less impressive because their $R \& D$ productivity grows at an extremely limited rate. Despite this difference in $R \& D$ productivity among industries, it is evident that no slowdown in R\&D productivity exists for Taiwanese firms.

Based on these various analyses, we confirmed that the R\&D productivity of Taiwanese firms continued increasing during the post-crisis period, suggesting that the decreasing R\&D productivity experienced by some advanced countries did not occur in Taiwan. Moreover, various analyses revealed a trend in R\&D productivity that has been ascending since the early 2000s. However, the continual increase in R\&D productivity for manufacturing firms has not stimulated higher economic growth in Taiwan. Therefore, the question of what causes the slowdown of economic growth in Taiwan is worth exploring further.

\section{Conclusion}

The story of Taiwan's post-war economic miracle is widely recognized among economists. The extraordinary post-war growth might be principally attributed to factors that accumulated before the 1990s, and tremendous technological progress has also significantly contributed to economic growth in the past two decades. After the Asian Financial Crisis, Taiwan's growth performance became substantially less impressive, relative to its East Asian counterparts. 
Considering the importance of innovation to economic growth, the question remains: Is the decline in economic growth caused by a decline in $R \& D$ productivity? This study posed this question and answered it by conducting microeconometric analysis. By employing alternative approaches to measuring $\mathrm{R} \& \mathrm{D}$ productivity in obtaining robust results, empirical results show that the overall R\&D productivity growth had stagnated very little in the early 1990 s, whereas the R\&D productivity of firms increased sharply from the mid-1990s and continued growing thereafter. Further investigation conducted by splitting the sample into electronics firms and other manufacturing firms yielded strong evidence that electronics firms have significantly higher performance in R\&D productivity relative to their non-electronics counterparts. This finding is consistent with the view that the electronics industry is more productive and efficient in Taiwan, enabling it to play a vital role in the global market.

The evidence that Taiwan's R\&D productivity is still ascending rather than descending suggests that the decline in R\&D productivity has not yet occurred, as it has in some advanced countries. Therefore, the decline in Taiwan's post-crisis economic growth cannot be ascribed to the decline in R\&D productivity. Some economists have argued that a large amount of outward FDI to China (which has caused the instability of this island's political environment), as well as international economic influences, might be the main causes of Taiwan's reduced economic growth in recent years. These arguments must be examined carefully; however, one point that can be confirmed is that the performance of low economic growth is not caused by the decreasing return to $R \& D$.

This study also provides two important implications for technology policy. First, measures such as tax incentives, financial assistance, R\&D grants, and other actions have been used by the government to promote $R \& D$ spending over the past two decades. Whether the government is effective in promoting the innovative capability of firms should be thoroughly evaluated. If the measures are effective, then the government can continue using these measures. Second, firms have effectively recognized the importance of innovation and have attempted to increase the efficiency of their R\&D operations. In the absence of strong domestic institutions whose research capability is at the forefront of global technology, one plausible and key strategy for promoting the technological capability of firms is to emulate Japanese and U.S. technological networks, because they are the two vital, long-term sources of imported technology.

\section{Acknowledgement}

We greatly acknowledge the helpful comments from the editor and three anonymous referees. We are responsible for all errors. 


\section{References}

Acemoglu, D.; Aghion, P.; Zilibotti, F. 2006. Distance to frontier, selection, and economic growth, Journal of the European Economic Association 4(1): 37-74.

http://dx.doi.org/10.1162/jeea.2006.4.1.37

Aghion, P.; Howitt, P. 1992. A model of growth through creative destruction, Econometrica 60: 323-351. http://dx.doi.org/10.2307/2951599

Ang, J. B.; Madsen, J. B. 2011. Can second-generation endogenous growth models explain the productivity trends and knowledge production in the Asian miracle economies?, The Review of Economics and Statistics 93(4): 1360-1373. http://dx.doi.org/10.1162/REST_a_00126

Audretsch, D. B.; Acs, Z. J. 1991. Innovation and size at the firm level, Southern Economic Journal 67(3): 739-744. http://dx.doi.org/10.2307/1059787

Beneito, P. 2001. R\&D productivity and spillovers at the firm level: evidence from Spanish panel data, Investiaciones Economicas 25: 289-313.

Branstetter, L.; Nakamura, Y. 2003. Is Japan's innovative capacity declined?, in A. Kashyap, J. Corbett, M. Blomstrom, F. Hayashi (Eds.). Structural Impediments to Growth in Japan. Chicago: University of Chicago Press, 191-223.

Chen, J. R.; Yang, C. H. 2006. The effects of knowledge capital on enhancing firms' productivity in Taiwan - does R\&D or technology import matter?, Hitotsubashi Journal of Economics 47(2): 137-153.

Cincera, M. 1997. Patents, R\&D, and technological spillovers at the firm level: some evidence from econometric count models for panel data, Journal of Applies Econometrics 12: 265-280. http://dx.doi.org/10.1002/(SICI)1099-1255(199705)12:3<265::AID-JAE439>3.0.CO;2-J

Cohen, W. M.; Nelson, R. R.; Walsh, J. P. 2000. Protecting their intellectual assets: appropriability conditions and why U.S. manufacturing firms patent (or not), NBER Working Paper Series No. 7552. Cambridge, MA.

Evenson, R. E. 1993. Patents, R\&D, and invention potential: international evidence, American Economic Review Papers and Proceeding 83(2): 463-468.

Griliches, Z. 1986. Productivity, R\&D, and basic research at the firm level in the 1970s, American Economic Review 76: 141-154.

Griliches, Z. 1990. Patent statistics as economic indicators: a survey, Journal of Economic Literature 28: 1161-1701.

Griliches, Z. 1994. Productivity, R\&D and the data constraint, American Economic Review 84(1): $1-23$.

Griliches, Z.; Mairesse, J. 1984. Productivity and R\&D at the firm level, in G. Griliches (Ed.). $R \& D$, Patents, and Productivity. Chicago, IL: University of Chicago Press, 339-374.

Grossman, G. M.; Helpman, E. 1991. Quality ladders and product cycles, Quarterly Journal of Economics 425: 557-586. http://dx.doi.org/10.2307/2937947

Hall, B. H. 2002. The financing of research and development, Oxford Review of Economic Policy 18: 35-51. http://dx.doi.org/10.1093/oxrep/18.1.35

Hall, B. H.; Mairesse, J. 1995. Exploring the relationship between R\&D and productivity in France manufacturing firms, Journal of Econometrics 65: 263-293.

http://dx.doi.org/10.1016/0304-4076(94)01604-X

Hall, B. H.; Ziedonis, R. H. 2001. The patent paradox revisited: an empirical study of patenting in the U.S. semiconductor industry, 1979-1995, RAND Journal of Economics 32: 101-128. http://dx.doi.org/10.2307/2696400 
Hausman, J. A.; Hall, B. H.; Griliches, Z. 1984. Econometric models for count data with an application to the patent-R\&D relationship, Econometrica 52: 909-938.

http://dx.doi.org/10.2307/1911191

Jones, C. 1995. Time series test of endogenous growth models, Quarterly Journal of Economics 110: 495-525. http://dx.doi.org/10.2307/2118448

Kortum, S. 1993. Equilibrium R\&D and the patent-R\&D ratio: U.S. evidence, American Economic Review Papers and Proceedings 83: 450-457.

Kortum, S. 1997. Research, patenting, and technological change, Econometrica 65: 1389-1419. http://dx.doi.org/10.2307/2171741

Lerner, J. 1995. Patenting in the shadow of competitors, Journal of Law \& Economics 38(2): 463-495. http://dx.doi.org/10.1086/467339

Licht, G.; Zoz, K. 1998. Patents and R\&D, an investigation using application for German, European and US patent by German companies, Annales d'Economie et de Statistique 49/50: 329-360.

Lichtenberg, F.; Siegel, D. 1991. The impact of R\&D on productivity - new evidence using linked R\&D-LRD data, Economic Inquiry 29: 203-229.

http://dx.doi.org/10.1111/j.1465-7295.1991.tb01267.x

Madsen, J. B. 2007. Are there diminishing returns to R\&D?, Economics Letters 95: 161-166. http://dx.doi.org/10.1016/j.econlet.2006.09.009

Madsen, J. B. 2008. Semi-Endogenous versus Schumpeterian Growth Models: testing the knowledge production function using international data, Journal of Economic Growth 13: 1-26.

http://dx.doi.org/10.1007/s10887-007-9024-0

Madsen, J. B.; Ang, J. B.; Banerjee, R. 2010. Four centuries of British economic growth: the roles of technology and population, Journal of Economic Growth 15(4): 263-290.

http://dx.doi.org/10.1007/s10887-010-9057-7

Madsen, J. B.; Saxena, S.; Ang, J. B. 2010. The Indian growth miracle and endogenous growth, Journal of Development Economics 93: 37-48. http://dx.doi.org/10.1016/j.jdeveco.2009.06.002

Romer, P. M. 1990. Endogenous technological change, Journal of Political Economy 98: S71S102. http://dx.doi.org/10.1086/261725

Sakakibara, M.; Branstetter, L. G. 2001. Do stronger patents induce more innovation? Evidence from the 1988 Japanese patent law reform, RAND Journal of Economics 32: 77-100.

Segerstrom, P. 1998. Endogenous growth without scale effects, American Economic Review 88: 1290-1310.

Trajtenberg, M. 2001. Innovation in Israel, 1968-1997: a comparative analysis using patent data, Research Policy 30: 363-389. http://dx.doi.org/10.1016/S0048-7333(00)00089-5

Yang, C. H. 2008. The effects of strengthening intellectual property rights in NIEs: evidence from Taiwan's 1994 patent reform, Contemporary Economic Policy 26(2): 259-275.

http://dx.doi.org/10.1111/j.1465-7287.2007.00095.x

Chih-Hai YANG is a Professor and the Director of Economics at National Central University, where he teaches courses on Economics of Innovation. He has published dozens of research articles in international journals. Prof. Yang is a member of the editorial boards of Asian Economic Journal.

Chia-Hui HUANG is a Assistant Professor in Department of Economics, Aletheia University, Taiwan. Her current research interests include Industrial Economics, Innovation Economics, and Applied Econometrics. 